\title{
De l'usure à la chasteté : la métaphore requalifiante
}

Sebastian T. McEvoy

\section{(2) OpenEdition}

Journals

\section{Édition électronique}

URL : http://journals.openedition.org/shakespeare/1248

DOI : 10.4000/shakespeare.1248

ISSN : 2271-6424

Éditeur

Société Française Shakespeare

Édition imprimée

Date de publication : 1 novembre 1993

Pagination : 39-55

Référence électronique

Sebastian T. McEvoy, «De l'usure à la chasteté : la métaphore requalifiante », Actes des congrès de la Société française Shakespeare [En ligne], 11 | 1993, mis en ligne le 01 janvier 2007, consulté le 21 avril 2019. URL : http://journals.openedition.org/shakespeare/1248; DOI : 10.4000/shakespeare.1248

Ce document a été généré automatiquement le 21 avril 2019

(C) SFS 


\section{De l'usure à la chasteté : la métaphore requalifiante}

Sebastian T. McEvoy 